\title{
Kewenangan Notaris Dalam Pendirian Perseroan Perorangan Berdasarkan Undang-Undang Nomor 11 Tahun 2020 Tentang Cipta Kerja
}

\section{Fajar Rafiqi Reynaldi}

Magister Kenotariatan Fakultas Hukum Universitas Islam Indonesia Yogyakarta Indonesia Jln. Cik Di Tiro No. 1 Yogyakarta Indonesia fajarrafiqi8@gmail.com

\section{Key Word: \\ Individual Company, Omnibus \\ Power of Notary}

\begin{abstract}
This study examines the authority of a notary in the establishment of an individual company based on Law Number 11 of 2020 on Job Creation. The problems formulated are first, how is the authority of a notary in the establishment of an individual company based on the amendment to Law Number 11 of 2020 on Job Creation, and second, what is the responsibility of a notary in the change in the establishment of an individual company based on Law Number 11 of 2020 concerning Job Creation. This type of research is normative with a statutory approach and a conceptual approach. The method used is literature study, and the data is processed non-statistically and analyzed descriptively-qualitatively. The results of the study conclude firstly, that a notary has no authority in the process of establishing a private company as regulated in the Job Creation Law and its derivative regulations Government Regulation Number 8 of 2021, the authorized capital of the company and the registration of the establishment, amendment, and dissolution of companies that meet the criteria for micro businesses. and Small. Second, the establishment of an individual company that meets the requirements for micro and small businesses is the responsibility of the person concerned (founder/shareholder), hence it is the responsibility of the person concerned, not the responsibility of a notary
\end{abstract}

Kata-kata Kunci:
Kewenangan
Notaris, Perseron
Perorangan, UU
Cita kerja,

\begin{abstract}
Abstrak
Penelitian ini meneliti tentang kewenangan notaris dalam pendirian Perseroan Perorangan berdasarkan Undang - Undang Nomor 11 Tahun 2020 Tentang Cipta Kerja. Masalah yang dirumuskan, pertama, bagaimana kewenangan notaris dalam pendirian Perseroan Perorangan berdasarkan perubahan Undang - Undang Nomor 11 Tahun 2020 Tentang Cipta Kerja, dan kedua, bagaimana tanggung jawab notaris dalam Perubahan pendirian Perseroan Perorangan berdasarkan Undang-Undang Nomor 11 Tahun 2020 Tentang Cipta Kerja. Jenis penelitian ini adalah normatif dengan pendekatan perundang-undangan dan pendekatan konseptual. Metode yang digunakan adalah dengan studi kepustakaan, dan data diolah secara non-statistik dan dianalisis secara deskriptif-kualitatif. Hasil penelitian menyimpulkan pertama, bahwa notaris tidak memiliki kewenangan dalam proses pendirian Perseroan Perorangan seperti yang telah diatur dalam UU Cipta kerja dan peraturan turunannya Peraturan Pemerintah Nomor 8 Tahun 2021 tentang Modal Dasar Perseroan Serta Pendaftaran Pendirian, Perubahan, dan Pembubaran Perseroan yang Memenuhi Kriteria untuk Usaha Mikro dan Kecil. Kedua, pendirian Perseroan Perorangan yang memenuhi syarat Usaha Mikro dan Kecil tersebut merupakan tanggungjawab yang bersangkutan (pendiri/pemegang saham), sehingga menjadi tanggung jawab yang bersangkutan, bukan menjadi tanggungjawab notaris
\end{abstract}




\section{Pendahuluan}

Kehadiran Perseroan Terbatas (PT) merupakan salah satu sarana untuk melakukan kegiatan ekonomi sudah menjadi suatu keniscayaan yang tidak dapat ditawar lagi. Kehadiran PT baik dalam skala kecil, menengah, maupun besar merupakan model yang paling banyak dan paling sering dilakukan saat ini, karena adanya pembatasan tanggung jawab di dalamnya. ${ }^{1}$ Peraturan yang mengatur PT telah diatur secara khusus di dalam Undang-Undang Nomor 40 Tahun 2007 tentang Perseroan Terbatas (selanjutnya akan disebut UUPT), sehingga merupakan suatu kemudahan bagi para pihak untuk mendirikan dan menyelenggarakan usaha PT karena telah disebutkan secara jelas dalam Undang-Undang.

PT didirikan berdasarkan perjanjian, hal ini menunjukkan sebagai suatu perkumpulan dari orang-orang yang bersepakat mendirikan sebuah badan usaha yang berbentuk perseroan terbatas. Oleh karena dasar pendiriannya menggunakan perjanjian maka pendirian PT tidak dapat dilepaskan dari syarat-syarat untuk sahnya suatu perjanjian menurut ketentuan yang ada dalam Pasal 1320 Kitab Undang-Undang Hukum Perdata. ${ }^{2}$ Ketentuan mengenai pendirian PT dalam Pasal 7 ayat (1) UUPT harus didirikan oleh paling sedikit 2 orang, di mana suatu PT berdiri dan/atau semata-mata karena perjanjian oleh dua orang atau lebih dengan akta resmi atau akta notaris. Jika ditinjau dari segi hukum perjanjian, pendirian Perseroan sebagai badan hukum, bersifat "kontraktual" (contractual, by contract") yakni berdirinya perseroan merupakan akibat yang lahir dari perjanjian. Selain bersifat kontraktual, juga bersifat "konsensual" berupa adanya kesepakatan untuk mengikat perjanjian mendirikan perseroan. ${ }^{3}$ Berdasarkan hal tersebut dikatakan bahwa untuk mendirikan suatu PT tetaplah memperhatikan tentang ketentuan umum pernjanjian (Pasal 1313 - 1319) dan syarat sahnya perjanjian (Pasal 1320 - 1337) Kitab undang-undang Hukum Perdata. Unsur-unsur yang harus dipenuhi antara lain: ${ }^{4}$

1. Adanya dua orang atau lebih untuk mendiriakan perseroan;

2. Adanya pernyataan kehendak dari pendiri untuk persetujuan mendirikan perseroan dengan mewajibkan semua pendiri mengambil bagian saham pada saat perseroan didirikan;

3. Perjanjian pendirian perseroan tersebut dinyatakan di hadapan notaris (notariel) dalam bentuk akta pendirian berbahasa Indonesia yang sekaligus memuat anggaran dasar perseroan.

Ketentuan Pasal 7 ayat (1) UUPT PT pendirian PT paling sedikit 2 orang atau lebih menegaskan bahwa akta notaris merupakan syarat mutlak untuk adanya suatu PT. Tanpa adanya akta otentik akan meniadakan eksistensi perseroan terbatas sebab akta pendirian inilah nantinya yang harus disahkan Kementrian Hukum dan Hak Asasi

\footnotetext{
${ }^{1}$ Binoto Nadapdap, Hukum Perseroan Terbatas (Berdasarkan Undang-Undang No.40 Tahun 2007), Jala Permata Aksara, Jakarta, 2016, hlm. 1

${ }^{2}$ Rudhy Prasetya, Kedudukan Mandiri Perseroan Terbatas, Citra Aditya Bakti, Bandung, 2004, hlm. 4-5.

${ }^{3}$ M. Yahya harahap, Hukum Perseroan Terbatas, Sinar Grafika, Jakarta, 2016, hlm. 35.

${ }_{4}^{4}$ Agus Budiarto, Kedudukan Hukum dan Tanggung Jawab Pendiri Perseroan Terbatas, Ghalia Indonesia, Jakarta, 2002 hlm. 3.
} 
Manusia. Sejalan dengan rumusan peraturan lama Pasal 38 KUHD dengan tegas mengatakan bahwa pendirian perseroan terbatas haruslah dengan akta otentik, ketiadaan akta notaris ini dapat menyebabkan perseroan terbatas dianggap tidak ada (batal). ${ }^{5}$

Pada 5 Oktober 2020 Dewan Perwakilan Rakyat (DPR) telah mengesahkan Rancangan Undang-Undang (RUU) Cipta Kerja. Setelah disahkannya Undang-Undang Nomor 11 Tahun 2020 tentang Cipta Kerja (selanjutnya disebut dengan UU Cipta Kerja) terdapat beberapa ketentuan dalam UU PT yang diubah dengan tujuan untuk kemudahan berusaha yang diatur dalam BAB II mengenai Asas, Tujuan, dan Ruang Lingkup Pasal 2 angka (1) huruf c yang dijelaskan pada bagian penjelasan mengenai kemudahan berusaha yaitu "Yang dimaksud dengan "kemudahan berusaha" adalah bahwa penciptaan kerja yang didukung dengan proses berusaha yang sederhana, mudah, dan cepat akan mendorong peningkatan investasi, pemberdayaan usaha mikro, kecil, dan menengah untuk memperkuat perekonomian yang mampu membuka seluasluasnya lapangan kerja bagi rakyat Indonesia."

Beberapa hal yang diubah dalam UU Cipta Kerja mengenai PT terkait dengan kemudahan berusaha yang diperjelas dalam Peraturan Pemerintah Nomor 8 Tahun 2021 tentang Modal Dasar Perseroan Serta Pendaftaran Pendirian, Perubahan, dan Pembubaran Perseroan yang Memenuhi Kriteria untuk Usaha Mikro dan Kecil adalah:

1. Status badan hukum perseroan;

2. Pengesampingan kewajiban PT harus didirikan oleh dua orang atau lebih;

3. Modal dasar;

4. Perseroan UMK dapat didirikan menggunakan pernyataan pendirian perseroan.

Diundangkannya UU Cipta Kerja dan Peraturan Pemerintah Nomor 8 Tahun 2021 tentang Modal Dasar Perseroan Serta Pendaftaran Pendirian, Perubahan, dan Pembubaran Perseroan yang Memenuhi Kriteria untuk Usaha Mikro dan Kecil saat ini dikenal ada sebuah Perseroan perorangan yang dapat didirikan oleh 1 orang. Adanya konsep perseoran perorangan juga memberikan dampak atas kewenangan dan tanggung jawab notaris dalam pembuatan akta pendirian perseroan perorangan berdasarkan UU Cipta Kerja dan serta bagaimana pendirian PT yang hanya menggunakan pernyataan pendirian perseroan yang disahkan secara elektronik oleh Menteri Hukum dan Hak Asasi Manusia. Di samping itu juga mengkaji kewenangan notaris sebagai pejabat umum agar tidak terjadinya kesalahan atau cacat hukum yang bertentagan dengan Undang-Undang dalam akta pendirian tersebut yang mengalami beberpa perubahan persyaratan pendirian.

\section{Rumusan Masalah}

Berangkat dari latar belakang masalah sebagaimana telah diuraikan diatas, maka fokus penelitian ini hanya akan merujuk pada dua persoalan utama yang akan dianalisis, pertama, bagaimana kewenangan notaris dalam pendirian

${ }^{5}$ Agus Budiarto, Op. Cit., hlm. 37. 
Perseroan Perorangan berdasarkan perubahan Undang - Undang Nomor 11 Tahun 2020 Tentang Cipta Kerja? dan kedua, bagaimana tanggung jawab notaris dalam perubahan pendirian Perseroan Perorangan berdasarkan Undang-Undang Nomor 11 Tahun 2020 Tentang Cipta Kerja?

\section{Tujuan Penelitian}

Penelitian bertujuan menganalisis kewenangan dan tanggung jawab notaris dalam pendirian Perseroan Perorangan berdasarkan Undang - Undang No 11 Tahun 2020 Tentang Cipta Kerja dan menganalisis tanggung jawab notaris dalam perubahan pendirian Perseroran Perorangan berdasarkan Undang-Undang No 11 Tahun 2020 Tentang Cipta Kerja.

\section{Metode Penelitian}

Pada penulisan penelitian ini, penulis menggunakan jenis penelitian normatif yang didukung dengan keterangan narasumber. Objek penelitian ini adalah regulasi yang terkait dengan kewenangan dan tanggungjawab notaris dalam perubahan pendirian Perseroran Perorangan yang meliputi sistem norma yang dimaksud sebagai objek kajian seluruh unsur dari norma yang berisi nilai-nilai tentang bagaimana seharusnya manusia bertingkah laku. Subjek penelitian ini adalah Notaris yang sudah berpraktik lebih dari 5 tahun yang juga sebagai akademisi.

Jenis data yang dipergunakan dalam penelitian ini adalah data kualitatif yang bersumber dari data primer dan data sekunder. Data primer adalah data yang bersumber dari hasil pengumpulan data dengan metode wawancara terhadap subyek penelitian. Sementara data sekunder bersumber dari bahan hukum primer dan bahan hukum skunder. Teknik pengumpulan data yang digunakan adalah studi pustaka, studi dokumen dan wawancara. ${ }^{6}$ Adapun pendekatan yang digunakan dalam penelitian ini adalah pendekatan perundang-undangan (Statue Approach), pendekatan konseptual. 7 Data diolah secara non-statistik dan dianalisis secara deskriptif-kualitatif.

\section{Hasil Penelitian dan Pembahasan}

\section{Kewenangan Notaris dalam Pendirian Perseroan Perorangan Berdasarkan Perubahan Undang-Undang No 11 Tahun 2020 tentang Cipta Kerja}

Kewenangan notaris sebagai pejabat umum tertuang pada Undang-Undang 30 Tahun 2004 tentang Jabatan Notaris sebagaimana telah diubah dengan Undang-Undang 2 Tahun 2014 tentang Perubahan Atas UU 30 Tahun 2004 tentang Jabatan Notaris. Kewenangan notaris sesungguhnya menjadi bagian penting dari negara Indonesia yang menganut prinsip negara hukum (Pasal 1 ayat (3) Undang-Undang Dasar Negara Republik Indonesia Tahun 1945. Prinsip negara hukum menjamin kepastian, ketertiban, dan perlindungan hukum yang berintikan kebenaran dan keadilan. Kepastian,

${ }^{6}$ Mukti Fajar \& Yulianto Achmad, Dualism Penelitian Hukum Normative Dan Empiris, Pustaka Pelajar, Yogyakarta, 2010, hlm. 161.

${ }^{7}$ M. Syamsudin, Operasionalisasi Penulisan Hukum, PT. Raja Grafindo Persada, Jakarta, 2007, hlm. 56 
ketertiban, dan perlindungan hukum menuntut, antara lain, bahwa lalu lintas hukum dalam kehidupan masyarakat memerlukan adanya alat bukti yang menentukan dengan jelas hak dan kewajiban seseorang sebagai subjek hukum dalam masyarakat. Akta otentik sebagai alat bukti terkuat dan terpenuh mempunyai peranan penting dalam setiap hubungan hukum dalam kehidupan masyarakat. Melalui akta otentik, menentukan secara jelas hak dan kewajiban, menjamin kepastian hukum, dan sekaligus diharapkan pula dapat dihindari terjadinya sengketa.

Dalam hal pendirian PT notaris memiliki peran penting berdasarkan kewenangannya yang diberikan oleh UUJN yakni pembuatan akta pendirian dan pemberian penyuluhan hukum sehubungan dengan pembuatan akta. Namun demikian, dengan diundangkannya UU Cipta Kerja dan peraturan pelaksananya yang berorientasi memberikan pengaturan kemudahan, perlindungan, dan pemberdayaan koperasi dan usaha mikro, kecil dan menengah. ${ }^{8}$

Pada auran teknis dalam PP No 8 Tahun 2021 tentang Modal Dasar Perseroan Serta Pendaftaran Pendirian, Perubahan, dan Pembubaran Perseroan yang Memenuhi Kriteria Untuk Usaha Mikro dan Kecil, proses pendirian perorangan perorangan hanya perlu mengisi form yang sudah disediakan di website pendaftaran. Sehingga notaris tidak memiliki kewenangan dalam proses pendirian perseroan perorangan.

Kewenangan notaris dalam ketentuan Pasal 15 ayat (2) huruf e UUJN yang menyatakan bahwa notaris berwenang pula memberikan penyuluhan hukum sehubungan dengan pembuatan akta juga tidak menjadi kewajiban karna surat pernyataan pendirian elektronik bukanlah akta otentik seperti yang diatur dalam UUJN maupun KUHPerdata. Jadi tidak ada kewajiban bagi notaris untuk melakukan penyuluhan hukum dalam proses pendirian perseroan perorangan. ${ }^{9}$

Berdasarkan hasil wawancara dengan notaris Habib Adjie, meskipun dalam pendirian Perseroan Perorangan tidak ada keterlibatan notaris, notaris sebagai penyuluh hukum kepada masyarakat wajib memberikan penjelasan dalam pendirian Perseroan Perorangan tersebut, hanya untuk membantu saja, karena pada dasarnya masyarakat belum tentu paham mengenai pendirian Perseroan Perorangan tersebut. ${ }^{10}$

\section{Tanggung Jawab Notaris dalam Perubahan Pendirian Perseroan Terbatas Berdasarkan Undang-Undang No. 11 Tahun 2020 tentang Cipta Kerja}

Dalam hal melaksanakan tugasnya seorang notaris mempunyai tanggung jawab terhadap jabatannya dan memiliki keharusan untuk bertanggungjawab kepada kliennya, serta atas semua tindakannya. Menurut Sudarsono, tanggung jawab yaitu keharusan kepada seseorang untuk melaksanakan secara selayaknya apa yang telah diwajibkan kepadanya. Tanggung jawab dipikul oleh pirbadi yang mampu bertindak secara moral.

\footnotetext{
8 Tri Nurhayati, Kajian Yuridis Sosiologis Terbadap Pemberlakuan Undang-Undang Nomor 11 Tabun 2020 Tentang Cipta Kerja Beserta Aturan Turunannya, artikel dalam Jurnal Kertha Semaya, No. 6. Vol. 9, Tahun 2021, hlm. 10321043.

${ }^{9}$ Wawancara dengan Rio Kustianto Wironegoro, selaku Notaris pada Kamis, 17 Juni 2021 pukul 10.00 WIB.

10 Wawancara dengan Habib Adjie, selaku Notaris pada Rabu, 30 Juni 2021 pukul 16.45 WIB.
} 
Obyek tanggung jawab adalah tindakan yang sungguh-sungguh manusiawi bertolak dari bagian manusia yang bertindak melalui kehendak bebas. Notaris dihadirkan oleh negara untuk membantu masyarakat, dan notaris sebagai subjek hukum yang memahami dan mengetahui hukum tidak dilarang untuk membantu masyarakat yang ingin mendirikan pendirian PT. Dengan diundangkanya UU Cipta Kerja proses pendirian Perseroan Perorangan tidak lagi memerlukan akta otentik yang dibuat oleh notaris. Notaris tidak memiliki lagi tanggung jawab terkait dengan surat pernyataan elektronik pendririan Perseroan Perorangan.

Berdasarkan hasil wawancara dengan notaris Habib Adjie pendirian Perseroan Perorangan yang memenuhi syarat UMK tersebut merupakan tanggungjawab yang bersangkutan (pendiri/pemegang saham), sehingga menjadi tanggung jawab yang bersangkutan, bukan menjadi tanggungjawab notaris karena dalam pendirian Perseroan Perorangan tidak ada keterlibatan notaris sama sekali, karena hal tersebut dapat dilakukan oleh pendiri sendiri dengan cara mengkakses situs di Kementerian Hukum dan Hak Asasi Manusia RI.

Tapi akan ada keterlibatan notaris jika Perseroan Perorangan tersebut dikonversi ke PT Persekutuan Modal (PT. Biasa menurut UUPT) karena PT. Perorangan sudah tidak memenuhi syarat UMK atau sebaliknya PT Persekutuan Modal (PT. Biasa) konversi ke Perseroan Perorangan karena memenuhi syarat UMK.11

\section{Penutup}

\section{Kesimpulan}

Notaris tidak memiliki kewenangan dalam proses pendirian Perseroan Perorangan seperti yang telah diatur dalam UU Cipta Kerja dan peraturan turunanya PP Nomor 8 Tahun 2021 tentang Modal Dasar Perseroan Serta Pendaftaran Pendirian, Perubahan, dan Pembubaran Perseroan yang Memenuhi Kriteria Untuk Usaha Mikro dan Kecil. Dalam proses pendirian Perseroan Perorangan hanya perlu mengisi form yang sudah disediakan di website pendaftaran. Sehingga tidak ada kewenangan notaris dalam proses pendirian Perseroan Perorangan tersebut.

Pendirian Perseroan Perorangan yang memenuhi syarat UMK tersebut merupakan tanggungjawab yang bersangkutan (pendiri/pemegang saham), sehingga menjadi tanggung jawab yang bersangkutan, bukan menjadi tanggungjawab notaris karna dalam pendirian PT.

\section{Saran}

Meskipun dalam pendirian Perseroan Peroangan tidak ada keterlibatan Notaris, tapi Notaris sebagai penyuluh hukum kepada masyarakat wajib memberikan penjelasan dalam pendirian Perseroan Perorangan tersebut, hanya untuk membantu saja, karena pada dasarnya masyarakat belum tentu paham mengenai pendirian Perseroan Perorangan tersebut.

${ }^{11}$ Wawancara dengan Habib Adjie selaku Notaris pada Rabu, 30 Juni 2021 pukul 16.45 WIB. 
Notaris dihadirkan oleh negara/pemerintah untuk membantu masyarakat, dan Notaris sebagai subjek hukum yang memahami dan mengetahui hukum disarankan untuk membantu masyarakat yang ingin mendirikan pendirian Perseroan Peroangan.

\section{Daftar Pustaka}

\section{Buku}

Budiarto, Agus, Kedudukan Hukum dan Tanggung Jawab Pendiri Perseroan Terbatas, Ghalia Indonesia, Jakarta, 2002.

Fajar, Mukti \& Yulianto Achmad, dualism penelitian hukum normative dan empiris, pustaka pelajar, Yogyakarta, 2010.

Nadapdap, Binoto, Hukum Perseroan Terbatas (Berdasarkan Undang-Undang No.40 Tahun 2007), Jala Permata Aksara, Jakarta, 2016.

Prasetya, Rudhy Kedudukan Mandiri Perseroan Terbatas, Citra Aditya Bakti, Bandung, 2004.

Syamsudin, M. Operasionalisasi Penulisan Hukum, PT. Raja Grafindo Persada, Jakarta, 2007.

Yahya Harahap, M., Hukum Perseroan Terbatas, Sinar Grafika, Jakarta, 2016.

\section{Jurnal}

Nurhayati, Tri, Kajian Yuridis Sosiologis Terhadap Pemberlakuan Undang-Undang Nomor 11 Tahun 2020 tentang Cipta Kerja Beserta Aturan Turunannya,, Jurnal Kertha Semaya, No. 6. Vol. 9, Tahun 2021.

\section{Perundang-undangan}

Kitab Undang-Undang Hukum Perdata

Undang-Undang Nomor 40 Tahun 2007 tentang perseroan Terbatas

Undang-Undang Nomor 11 Tahun 2020 tentang Cipta Kerja

Peraturan Pemerintah Nomor 8 Tahun 2021 Modal Dasar Perseroan Serta Pendaftaran Pendirian, Perubahan, dan Pembubaran Perseroan yang Memenuhi Kriteria Untuk Usaha Mikro dan Kecil. 